\title{
稻胡麻葉枯病に扮ける脱水素醭素の組織化学的証明*
}

\author{
野 津幹 雄 ${ }^{* *}$ \\ Mikio Nozu : Histochemical demonstrations of dehydrogenases in the \\ rice plant tissues affected by Cochliobolus miyabeanus \\ and in the causal fungus.
}

テトラゾリウム塩による植物の組織化学的観察 は往来から行われており, Seligman らは triphenyl tetrazolium chloride (TTC) を用い ${ }^{5}$, Dayer は 3,5-diphenyl tetrazorium chloride (blue tetrazolium，BT）を用いて11，それぞれ実験している。 植物病理学の 分野では鈴木がイモチ病に ${ }^{8}$, また Mustakario が甘藷紫紋羽病に3)，それぞれ TTCを 用いている。また生化学的には各種の病書または病原 菌において脱水素酵素の活性が 追究されている ${ }^{9,10)}$ 。 筆者は脱水素酵素と特異的に反応するといわれている $\mathrm{BT}^{2)}$ を用い，稻乩麻葉枯病病斑拡大と本酵素の活性 部位との関係を中心に, 若干の実験を行つたのでここ にその結果を報告する。

起稿にあたり御羃陶を賜つた泉根農科大学山本昌木 教授ならびに実験を指導された名古屋大学農学部平井 篤造，瓜谷郁三両教授に厚く感謝の意を表する。

\section{I. 実験材料および方法}

供試水稻の品種は愛知旭で, $\frac{1}{5 \text { 万 } ワ ゙ ネ ル ホ ゚ ッ ト に ~}$ 50 粒づつ播種した。供試葉身および葉鞘は第 10 葉 が展開しつつある稻の第 8 葉および第 9 葉のものであ る。酵素活性の存在部位を知るためには, 比較的大き な葉緑体をもつているホーレンソウ (Spinacia oleracea Mill.) およびダイズ (Glicine max Merr.) を併用 した。

稲乩麻葉枯病菌は 1956 年 1 月罹病籹から, 筆者が 純粋分離した菌株である。本病菌を稻賞煮汁寒天で $30^{\circ} \mathrm{C}$ で 10 日間培養し, 新たに形成された分生胞子 を接種ならびに菌の組織化学的観察に用いた。脱水素 酵素の組織化学的㭘出は次のよ 5 に行つた ${ }^{1,5)}$ 。0.1\% BT 溶液 $1 \mathrm{cc}+0.1 \mathrm{M}$ 燐酸緩衝液 ( $\mathrm{pH} \mathrm{7.4)} 1 \mathrm{cc}+$ $0.2 \mathrm{M}$ コハク酸ナトリウム溶液 $1 \mathrm{cc}+$ 蒸溜水 $1 \mathrm{cc}=$

* 本実験の一部は昭和 33 年度日本植物病理学会大 会に括いて発表した。名大植病教室業績第 38 号

** 名古屋大学農学部植物病理学教室, 現在 島根農 科大学
計 $4 \mathrm{cc}$ をツンぶルグ管に入れ，その中に供試材料を投 入し, 水銀柱 3 5 $\mathrm{mm}$ で材料中に試験液を真空透入 させた。 $30^{\circ} \mathrm{C}, 2$ 時間後試料をとり出し，通常これ を徒手切片として検鏡，観察した。

\section{II. 実験結果および考察}

\section{1. 稲葉組織の BT 反応に要する時間ならびに着 色部位}

稻葉各部から切片を作り， $30 \sim 32^{\circ} \mathrm{C}$ 明所または 暗所で BT 溶液と反応させ，時間の経過にともなう 着色度合を顕微鏡下で観察した。その結果は第 1 表に 示した。筆者の実験では反応度合は BT 溶液処理 8 時間後で一定となり，反応しうる細胞は濃青紫色にな つた。しかし BT 処理 4 時間後は着色部分に变化は なく，処理 2 時間後で観察に充分な反応が一応見られ た。ホーレンソウおよびダイズでも反応にはほぼ同様 の時間を要した。

第 1 表 稲葉に拈ける BT の反応所要時間

\begin{tabular}{|c|c|c|c|c|c|c|c|c|}
\hline & 材料 \反応時間 & 0 & 1 & 2 & 4 & 6 & 8 & 24 \\
\hline \multirow[b]{2}{*}{ 明 } & 9 葉（中央） & - & + & H & $H$ & $H$ & Ht & H \\
\hline & 10 葉 葉鞘 & \pm & + & H & $H$ & III & HH & H \\
\hline \multirow[t]{3}{*}{ 所 } & 4 葉（先 & - & \pm & + & + & + & H & itt \\
\hline & 4 葉 (中 & - & \pm & + & + & + & + & H \\
\hline & 9 葉 (中央) & - & \pm & + & H & $H$ & H & H \\
\hline 暗 & 10 葉 葉鞘 & \pm & + & H & Ht & tIt & $H$ & H \\
\hline \multirow[t]{2}{*}{ 所 } & 4 葉（先端） & - & - & \pm & \pm & + & + & + \\
\hline & 4 葉（中央） & - & - & \pm & + & $\uparrow$ & + & + \\
\hline
\end{tabular}

備考：十〜卅は反応の強さの程度を示す

水稲葉身の BT 反応は葉緑粒を含む細胞に顕著で あつて（第 1 図，a，b），表皮細胞，厚膜細胞，機動 細胞および 維管束組織には明らかでなかつた（第 1 図，b）。また展開前の葉鞘には特に強い反応が見られ 
第1図稲に打けるBT反応部位

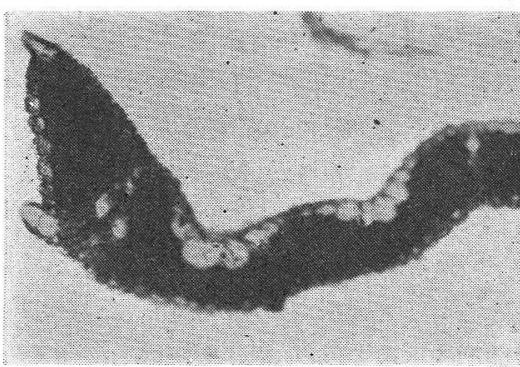

a.

a：葉身に拈ける反応部位（反応処理 4 時間） c：展開前の葉鞘に括けるBT 反応

た（第 1 図，c）。

上記の着色反応は試料のホルマリン処理 $(10 \%, 1$ 時間）または熱処理 $\left(50 \sim 60^{\circ} \mathrm{C}, 10\right.$ 分）によつて消 失した。一般に BT 溶液による反応至適温度は $37^{\circ} \mathrm{C}$ とされているが2)，本実験では $20^{\circ} \mathrm{C}$ から観察に充分 な反応が見られた。しかし供試材料が稻であることを 考慮して本実験は $30^{\circ} \mathrm{C} て ゙$ 行つた。また低温（冷蔵庫 内）ではこの反応は認められなかつた。以上の観察か ら本実験の BT 反応に関与する酵素系はコハク酸脱 水素酵素であると考えられるが, 本反応は基質(コハク 酸ナトリウム)を加えなくても着色が認められるので，

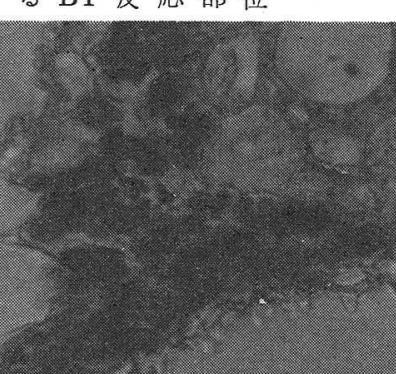

b.

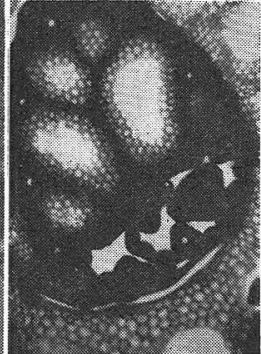

c.

b：BT 反応によって着色した葉緑体を含む細胞

ここでは単に脱水素酵素として取り扱うこととする。

\section{2. 稲葉に私け台脱水素酵素の存在場所}

前述のよ5に BT 反応は葉緑体を含む細胞に打い て顕著であつたが，更に細部にわたつてこれを観察す るため, 市販のホーレンソウおよびダイズの子葉を併 用した。その結果，BT 反応部位は明かに葉緑体で㐫 り(第 2 図), 着色顆粒は形態学的に葉緑体のグラナに 相当すると思われた（第 2 図，c，矢印）。Dayer はテ トラゾリウム塩の光化学的還元は緑色植物では grana like region に局在し，ある種の細胞では $3 \sim 4 \mu の$ 直径をもつ leucoplast に脱水素酵素活性があると述

第 2 図葉緑体を含む細胞に招ける脱水素酵素の存在部位

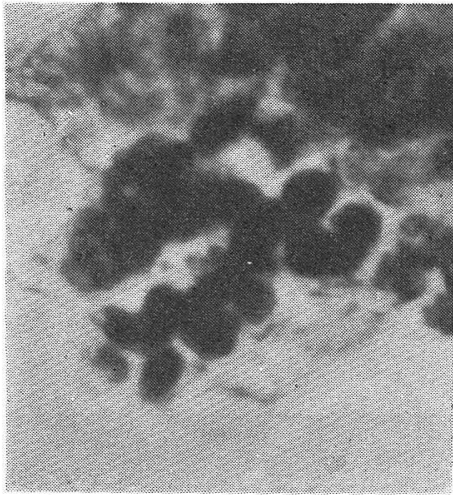

a : 稻

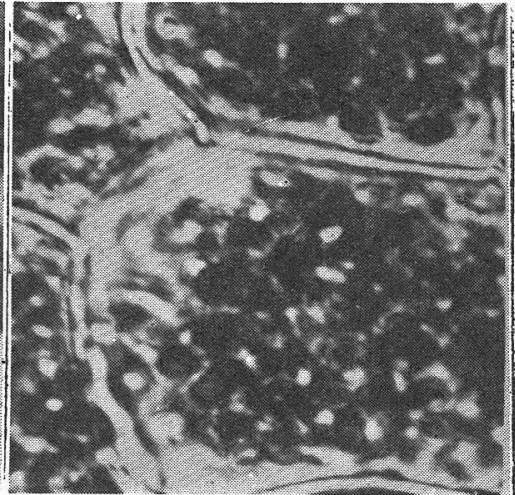

b.

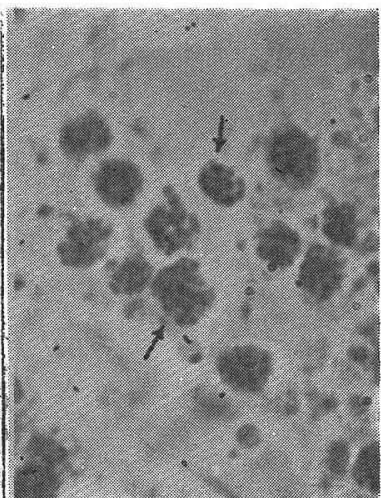

c.
ベている1)。筆者はいまだ本酵素活性の所在がグラナ にあると結論する確証をもたないので， BT 反応はグ ラナに相当する部位に顕著であつた事実を述べるにと どめたい。

\section{3. 稲胡麻葉枯病病斑の形成と脱水素酵素の活性 部位}

葉身に稻胡麻葉枯病菌を接種し，病斑形成過程と本
酵素活性部位との関係を観察した。この場合，病斑部 の断面が直接反応溶液にふれるように組織片を作り， 組織片のまま BT 溶液で処理し，処理後直らにそれ から切片を作つて検鏡した。稻胡麻葉枯病病斑は接種 後 20 時間以内に肉眼で認められる大きさになるが， 水浸状であつて葉脈間に限られ，接種後 $24 \sim 48$ 時間 で葉脈を通りこして拡大する。72 時間（3 日）後病 
斑部の褐変は顕著になり，中毒部との境界が明膫にな つた。中毒部は葉緑体の形態的異常のみから観察する と, 細胞にして 7 層内外であつた。本実験では接種後 96 時間 (4日目) と 168 時間 (7日目) の材料に抒 いて，病斑の大きさはほぼ同じであつた。

一方脱水素酵素の活性は病斑拡大初期，すなわち機 動細胞の一部が裼変した程度では機動細胞に隣接した 細胞にのみ強い反応が現われた(第 3 図,a)。機動細胞 全体が褐変すると，褐变機動細胞を含む葉脈間の緑色 組織に強い反応が現われた（第 3 図，b）。接種後 24 時間経過して 1 葉脈を通り越した病斑においては，病
斑の周辺に隣接する 2 つの葉脈間の組織に強い反応が みられた。接種後 48 時間の病玟は次第に拡大しつつ あるが，BT 反応部分に関して接種後 24 時間のもの と大差はなかつた。それ以後病斑の大きさに比較して BT 反応部分は小さくなり，72９6 時間の病斑では 褐变部に 接した組織にのみ反応が認められた（第 3 図，c）。これ以後病斑周辺に拈ける BT 反応は健全 組織における反応と区別できなかつた。なお接種後 5 〜 日の典型的病斑では，褐変部細胞には BT 反応 は認められず，中毒部細胞に和けるそれは健全組織の ものより弱かつた。

第 3 図 稲胡麻葉枯病の病斑形成と脱水素酵素の活性部位

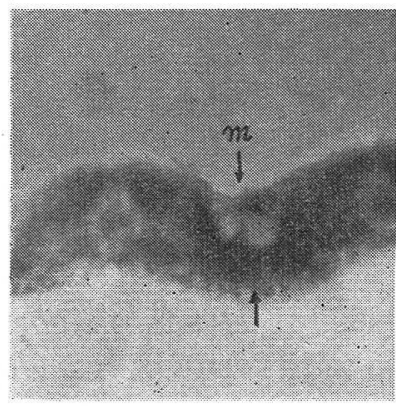

a.

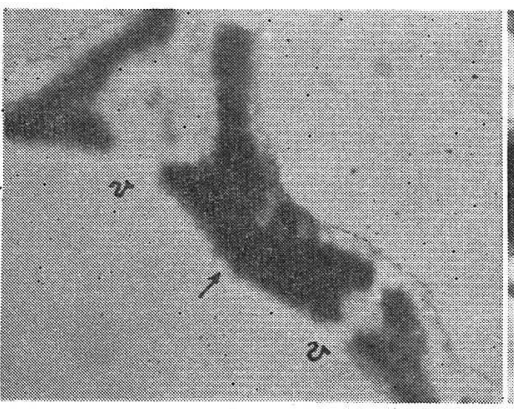

b.

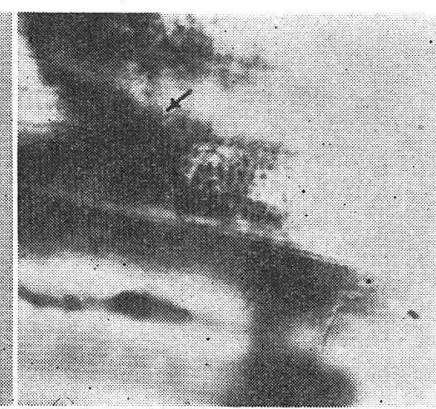

c.

$\mathrm{a}$ : 接種後 20 時間の反応 $\mathrm{m}$ : 機動細胞, 矢印は反応部位 $\mathrm{b}$ : 接種後 24 時間の反応 $\mathrm{v}$ : 葉脈, 矢印は反応部位 $\mathrm{c}$ : 接種後 $72 \sim 96$ 時間の反応，たたし病斑周辺の BT 反応（矢印）

\section{4. 葉鞘暠面表皮細胞への菌糸の侵入と脱水素酵素} 反応

以上のように葉身に拉ける病班拡大過程と本酵素活 性部分の消長とが密接に関係していることは認められ たが，菌糸の侵入部位と酵素活性との関係を観察する ことは困難であつた。そこで葉鞘異面表皮組織を使用 した。しかし該表皮細胞に护ける本酵素活性は極めて
弱く，菌糸の侵入による寄主細胞の酵素活性を観察す る試みは不可能であつた。一方侵入菌糸には強い反応 が認められ，侵入菌糸全体が濃青紫色になることが多 かつた（第 4 図，a）。 また侵入菌䒺の 着色の強さは BT による着色顆粒の多少によるもので，侵入菌杀内 には大小の反応陽性顆粒が散在していた（第 4 図, b)。 鈴木の報告によれ(゙゚),イモチ病菌を接種した葉鞘裏

第 4 図葉粗接種と BT 反応

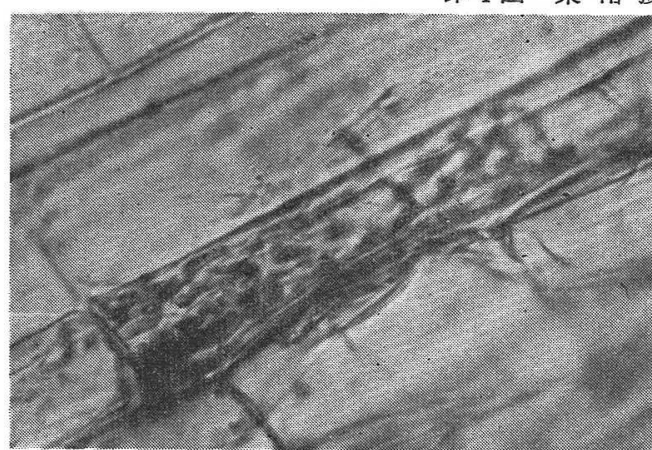

a.

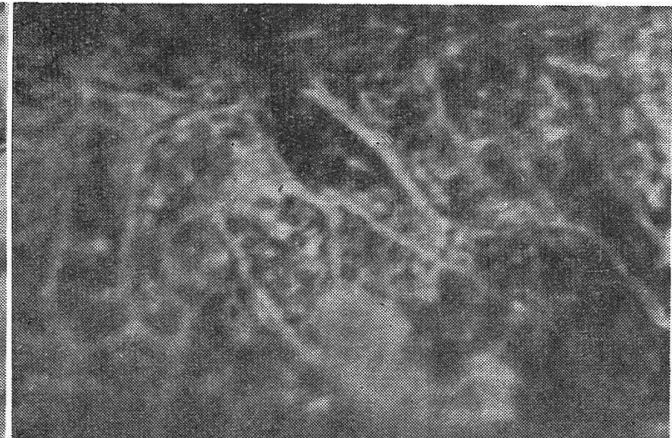

b.

a : 侵入菌糸に特ける BT 反応 b : 侵入菌糸内の着色顆粒 
面細胞に扣いて，まず附着器に脱水素酵素作用が強く 現れ，菌の侵入部位に接した稻細胞内の粒子に強い反 応が出ている。筆者の実験では附着器に関しては上と 同じであるが，侵入部位に接した寄主細胞に强い反応 は認め難く，健全部の反応と区別できなかつた。この 相違はおそらく使用した稲品種の本病菌に対する反応 の差違に基づくものであろう。しかし侵入菌糹内部に は強い反応が認められた。

\section{5. 稻胡麻葉枯病菌分生胞子の発芽と脱水素酵素}

前述のよ 5に侵入菌糸に执いて本酵素活性が顕著で あつたので，菌のみを対象として観察した。スライド ガラス上に胞子懸濁液を噴霧し，腤所 $30^{\circ} \mathrm{C}$ 湿室に放
置し， 2 時間ごとにスライドをとり出し，反応溶液を 加え, ツンベルグ管の代りに真空デシケーターを使用 して反応せしめた。その結果 BT 反応は胞子の細胞 質内にのみ現れた（第 5 図，a）。発芽処理 2 時間後, 胞子の両端の原形質において極めて強い反忘が現れ， 発芽管の反応は皆無に近かつた（第 5 図，b）。4 時間 後, 胞子の両端の 原形質では 2 時間後のるのと変ら ず，発芽管に特いては先端部よりも基部に反応が強か つた。また胞子全体の反応は強くなつた。6 時間後, 胞子の両端の原形質と特に附着器に拈いて顕著な反応 が現われた（第 5 図，c）。胞子においても侵入菌糸と 同様な反応陽性の着色顆粒が認められた。高等動植物

第 5 図胞子の発芽とBT 反応

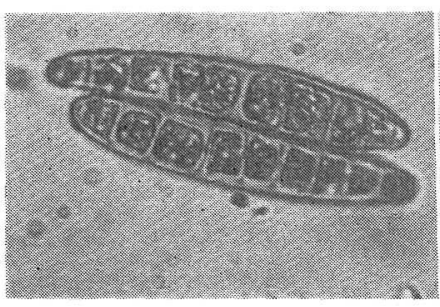

a.

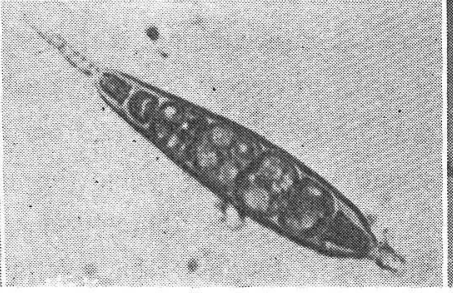

b.



c.

$\mathrm{a}$ : 発芽处理直後, 反応は弱いが均一火着色する b : 同 2 時間後, 胞子の両端が特に強い

c : 同 6 時間後, 胞子の両端および附着器が着色する

の場合，ミトコンドリアはテトラゾリウム塩を還元す るし6)また組織をホモジェネートしたものでは,大部 分のコハク酸脱水素酵素の活性はミトコンドリアの分 劃に見出されている7)。稲测麻葉枯病菌分生胞子にミ トコンドリアが存在することは確認しているので), 本病菌に和ける脱水葉酵素の存在場所はミトコンドリ アであると思われる。

\section{III. 摘 要}

病植物異常代謝を追究する一端として，稻乩麻葉枯 病罹病葉に拈ける脱水素酵素の活性を， blue tetrazolium（BT）を用いて組織化学的に観察した。その 結果, 稲葉に护ける BT 反応の存在は柔組織細胞で あつて，導管，厚膜細胞，機動細胞，表皮細胞に括い て認められなかりた。稻葉の病斑拡大と関連して組織 の裩変部分の周辺に強い反応が現れ，病斑が一定の大 きさになるに従つて反応部分は消失した。接種 5 日以 後の典型的病斑に抽いて BT 反応は褐変細胞には認 められず，中毒部の反応は健全部より弱かつた。葉鞘 裏面表皮細胞には極めて弱い反応があるのみで，菌糸 が侵入してもそれによつて特別の反応は現われなかつ
た。一方侵入菌糸には極めて強い反応があつた。胞子 の発芽過程に括いては, 胞子の両端の原形質に強い反 応があり，それにもまして附着器に和ける反応は顕著 であつた。なお BT 反応によつて認められる本酵素 の存在は稲葉では葉緑体のグラナに相当する部分であ り，稲胡麻葉枯病菌ではミトコンドリアであると推察 された。

(1959 年 3 月 20 日受理)

\section{引用 交 献}

1) Dayer, M.T. (1959), Amer. J. Botany, $40: 20$.

2) Lison, L. (1956), Histochimie et cytochimie, principes et méthodes, (今泉正訳) 白水社, p. 436 .

3) Mustakallio, K.K. and Telkkä, A. (1953). Science, $118: 320$.

4) 野津幹雄 - 松井千秋 (1959), 日植病報, 印刷中.

5) Seligman, A. M. and Rutenburg, A. M. (1951), Science, $113: 317$.

6) 新家浪雄 (1957), 細胞学, 岩波書店, p. 52. 
7）新家浪雄（1956）, 同上, p. 56.

9) 高村芳三郎 (1957), 日植病報, $22: 225$.

8）鈴木直治（1953），農技研研究報告， $7: 64$.

10）山口昭（1955), Virus (Japan), $6: 1$.

\section{Summary}

Dehydrogenase activity in the rice plant tissues inoculated with Cochliobolus miyabeanus (Helminthosporium leaf-spot fungus) and in the causal fungus was investigated using blue tetrazolium (BT). This reaction was positive in the sections of healthy leaf tissues after 2 hours' incubation at $30 \sim$ $32^{\circ} \mathrm{C}$ and the rate of the staining became constant after 8 hours' incubation. The reaction was negative when the sections were pretreated with formalin $\left(10 \%, 1 \mathrm{hr}\right.$. ) or treated at $50 \sim 60^{\circ} \mathrm{C}, 10$ min. In leaf tissues, the parenchymatous cells were most strongly stained and the sites of the enzyme activity seemed to lie on grana-like region in chloroplasts.

The leaf spot caused by the present fungus became visible 20 hours after inoculation. The dehydrogenase activity in this early stage of infection was demonstrated in cells near browned epidermis. With the enlargement of spotted area, the tissue around the lesion stained with BT; but the reaction became constant 48 hours after inoculation, although the enlargement of the lesion was. still proceeding. In the typical leaf spot produced $5 \sim 7$ days after inoculation, localization and intensity of formazan deposition could not be distinguished from those in healthy leaf tissue.

The reaction was weak in leaf-sheath cells even when the pathogen penetrated them. On the other hand, the penetrating hyphae, especially the appressoria and the germ tubes, showed strong. reaction. When the spores germinated on slide-glass, the reaction was detected on the terminal cells of the spores and on the germ tubes as well as on the appressoria. This positive reaction on spores of the present fungus seemed to localize on mitochondria of the fungus. (Plant Pathology Laboratory, Faculty of Agriculture, Nagoya University, Anzyo, Aichi-Ken)

\section{文献紹介}

\section{Alternaria solani の細胞学的研究}

Stall, R.E. : An investigation of nuclear number in Alternaria solani. Amer. J. Bot., 45;657 659. (1958).

この報告は A. solani とみられる変異がへテロ カリオシスに基くことを細胞学的に証明せんとした ものである。供試菌は改修 Hrushovetz 法 (3\%” ロリンで 15 分間隇菌した $1 \times 2 \mathrm{~cm}$ のセロフナン を平面培地上飞無菌的に置き，培地飞菌を接種，七 ロファン上へ発育させる）でセロフナン上に菌が適 度に発育した時セロフっンと共に Craf 液で固定, 水洗， $\mathrm{NaOH}$ の微量を加えた $2 \% \mathrm{H}_{2} \mathrm{O}_{2}$ で漂白， デラフィールドーマトキシリンで染色， 1 夜水中に 清け， 5 秒間酸性水中に入れて細胞質を脱色， 0.5 $\% \mathrm{LiCO}_{3}$ 中に 1 分間入れて核の染色を強化, 脱水 後 diaphane でマウントした。

菌系細胞中の核数は $1 \sim 7$ 個，普通 1 3 個，た だし先端細胞は 1 9 個，普通 4〜6 個 ; 担子梗細
胞中の核数は 1 4 個, 普通 1 あるいは 2 個; 分生 胞子原基は 1〜3 核であつた。成熟した分生胞子の 細胞も多核で基部のものほど多く（最多 8），先端 のものは 1 2 個，核の多いものほど細胞は大きか つた。発芽管はどの細胞からも形成され，その核数 は菌禾と同様であつたが，分生胞子の細胞から発芽 管中へ移行する核は 1 個以上らしい。

菌系はよく anastomosis を行い，完全汇細胞質 が連結するが，連結の起らない pseudoanastomosis もみられた。菌糸でも担子梗でも伸長, 多核となつ てから隔膜で区切られるので細胞は 1 または多核と なる。隔膜には孔がありここれを通して核は移動す る。

上述のよ5に細胞は多核で hyphal anastomosis 及び隔膜孔を通して核の交換移動が行われへテロカ リオンが形成され，dissociation が起つて変異が起 ると考元られる。単核の細胞から形成される菌系あ るいは分生胞子は遗伝的に安定であろ5。

$$
\text { (敛木橋雄) }
$$

